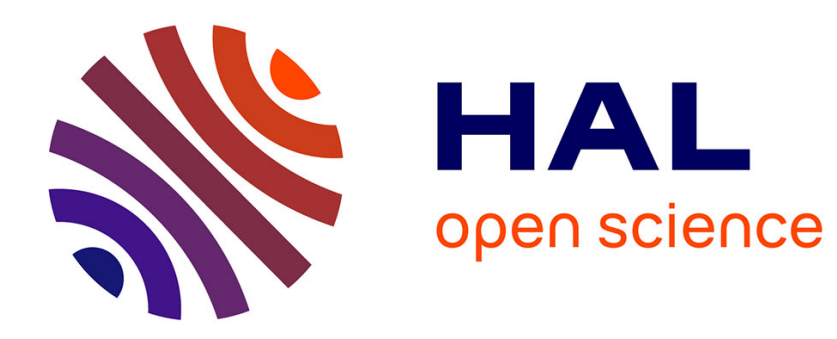

\title{
Rapid visual-motion integration deficit in autism
}

Bruno Gepner, Daniel Mestre

\section{To cite this version:}

Bruno Gepner, Daniel Mestre. Rapid visual-motion integration deficit in autism. Trends in Cognitive Sciences, 2002, 6 (11), pp.455. hal-00250048

\section{HAL Id: hal-00250048 \\ https://hal.science/hal-00250048}

Submitted on 8 Feb 2008

HAL is a multi-disciplinary open access archive for the deposit and dissemination of scientific research documents, whether they are published or not. The documents may come from teaching and research institutions in France or abroad, or from public or private research centers.
L'archive ouverte pluridisciplinaire HAL, est destinée au dépôt et à la diffusion de documents scientifiques de niveau recherche, publiés ou non, émanant des établissements d'enseignement et de recherche français ou étrangers, des laboratoires publics ou privés. 


\section{Rapid visual-motion integration deficit in autism}

Since the first description of childhood autism by Kanner in 1943, this syndrome has progressively been differentiated along a continuum of autistic spectrum disorders (ASD), on the basis of various levels of sensorimotor, verbal, cognitive and social disabilities. Several neuropsychological hypotheses have already been proposed to clarify the underlying mechanisms of these disorders. We propose here that a visual-motion integration deficit constitutes a crucial neuropsychological marker for at least a subgroup of ASD, according to the following arguments.

First, several autistic adults have reported severe difficulties in processing fast-moving visual events, as well as compensatory strategies aimed at slowing down the speed of movements, such as switching on and off the light or blinking rapidly [1]. Second, children with autism exhibit higher motion-coherence thresholds than normal children [2]. This result has recently been confirmed by our group: children with autism showed very weak oculomotor reactivity (deficient optokinetic nystagmus) to visual motion of a coherent pattern, especially at high speeds, compared with normal children of the same age or even younger. Third, autistic children are deficient in motiondirection discrimination [3]. Fourth, children with autism have a very weak postural reactivity to visually perceived environmental motion [4], especially at fast speeds [5], whereas children with Asperger syndrome (i.e. high functioning autistic children without verbal or cognitive delay) present normal postural reactivity or even over-reactivity to the same type of stimuli [5]. Finally, autistic individuals perform very poorly in facial recognition tasks involving the processing of facial dynamics, such as emotional expressions and movements of the lips and eyes, which are essentially rapid movements. Conversely, they perform relatively well in emotional and facial speech recognition tasks when the stimuli are displayed slowly on video [6].

It has already been suggested that this visual-motion integration deficit involves anomalies of magnocellular pathways [2,5] and visuo-cerebellar circuits [5] on the one hand, and anomalies of cerebello-premotor-motor cortex loops on the other [5]. This is based on three neurophysiological findings: (i) the implication of the magnocellular pathway in processing visual motion; (ii) the role of the cerebellum in speed and temporal coding of dynamic visual inputs; and (iii) the co-contributions of cerebellum and basal ganglia to real-time fine-tuning of motor outputs, and to motor learning via their projections to the motor and premotor cortices, as well as to the prefrontal, temporal and parietal cortices. The discovery of hypo- and hyperplastic cerebellar vermis lobules VI and VII involving Purkinje cells in autistic adults [7] gives strong support to the suggestion that cerebellar anomalies are involved. Furthermore, it was found that specific damage to the same cerebellar vermis lobules was responsible for a deficit in the accuracy of ocular saccades [8], and thus it could have a negative impact on visual-motion integration.

Concerning the specificity of the visual-motion integration deficit in autism, it is now well documented that dyslexic subjects also exhibit abnormalities in visual-motion sensitivity, which are also probably related to a magnocellular deficit [9]. It is thus possible that autism and dyslexia share a common visual-motion integration impairment, at least at a visuo-oculomotor level. However, individuals with autism are also deficient in visuo-postural control and fast visual motion processing. It is conceivable, then, that the motion integration deficit is at a deeper level in autism than in dyslexia, and that the neurodevelopmental consequences of this motion integration deficit are more pervading in autism than in dyslexia. In order to assess this question, further experiments involving both autistic and dyslexic subjects are required.

A motion integration deficit could account, through several neurodevelopmental cascades, for some of the major behavioral disorders manifested by children with ASD, such as their abnormal visuomotor reactivity, motor clumsiness, verbal and gestural imitation deficits, and impairments in socio-emotional interactions [5]. It might also account for their islets of ability and even increased performance in tasks involving static and/or local processing of information [10], and their atypical cognitive style and higher-order cognitive peculiarities [11]. We believe our hypothesis is thus also compatible with one of the major contemporary neuropsychological approaches of ASD, the weak central-coherence hypothesis $[10,11]$.

Finally, from a re-educational point of view, guidelines for slowing down the speed of environmental (physical and human) movements could logically contribute to verbal and emotional rehabilitation [6], and visuo-posturomotor integration [5] in this population. Virtual reality could be of great help in this context.

\section{Bruno Gepner*}

Child Psychiatry Department, Montperrin Hospital, and UMR-CNRS 6057, University of Provence, Aix-en-Provence, France. *e-mail: bruno.gepner@wanadoo.fr

\section{Daniel Mestre}

Center of Cognitive Neurosciences, CNRS, Marseille, France.

\section{References}

1 Williams, D. (1992) Nobody Nowhere, Doubleday

2 Milne, E. et al. (2002) High motion coherence thresholds in children with autism. J. Child Psychol. Psychiatry43, 255-263

3 Bertone, A. et al. Motion perception in autism: a 'complex' issue. J. Cogn. Neurosci. (in press)

4 Gepner, B. et al. (1995) Postural effects of motion vision in young autistic children. NeuroReport $6,1211-1214$

5 Gepner, B. and Mestre, D. (2002) Postural reactivity to fast visual motion differentiates autistic from children with Asperger syndrome. J. Autism Dev. Disord. 32, 231-238

6 Gepner, B. et al. (2001) Motion and emotion: a novel approach to the study of face processing by young autistic children. J. Autism Dev. Disord. $31,37-45$

7 Courchesne, E. et al. (1993) Abnormality of cerebellar vermian lobules VI and VII in patients with infantile autism: identification of hypoplastic and hyperplastic subgroups with MR imaging. Am. J. Roentgenol. 162, 123-130

8 Lewis, R.F. and Zee, D.S. (1993) Ocular motor disorders associated with cerebellar lesions: pathophysiology and topical localization. Rev. Neurol. (Paris) 14, 665-677

9 Talcott, J.B. et al. (2000) Visual motion sensitivity in dyslexia: evidence for temporal and energy integration deficit. Neuropsychologia 38, 935-943

10 Frith, U. (1989) Autism: Explaining the Enigma, Blackwell

11 Happé, F. (1999). Autism: Cognitive deficit or cognitive style? Trends Cogn. Sci. 3, 216-222 